\title{
Article \\ Not Only Antimicrobial: Metronidazole Mitigates the Virulence of Proteus mirabilis Isolated from Macerated Diabetic Foot Ulcer
}

\author{
Ahdab N. Khayyat ${ }^{1}$, Hisham A. Abbas ${ }^{2}{ }^{(D}$, Mamdouh F. A. Mohamed $^{3}{ }^{(D,}$, Hani Z. Asfour ${ }^{4}$, Maan T. Khayat ${ }^{1}$,

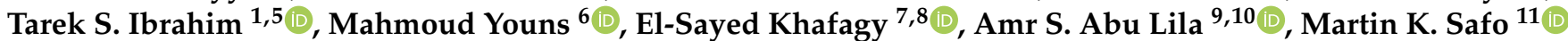 \\ and Wael A. H. Hegazy $2, * \mathbb{D}$
}

1 Department of Pharmaceutical Chemistry, Faculty of Pharmacy, King Abdulaziz University, Jeddah 21589, Saudi Arabia; Ankhayyat@kau.edu.sa (A.N.K.); mkhayat@kau.edu.sa (M.T.K.); tmabrahem@kau.edu.sa (T.S.I.)

2 Department of Microbiology and Immunology, Faculty of Pharmacy, Zagazig University, Zagazig 44519, Egypt; hishamabbas2008@gmail.com

3 Department of Pharmaceutical Chemistry, Faculty of Pharmacy, Sohag University, Sohag 82524, Egypt; mamdouh.fawzi@pharm.sohag.edu.eg

4 Department of Medical Microbiology and Parasitology, Faculty of Medicine, King Abdulaziz University, Jeddah 21589, Saudi Arabia; hasfour@kau.edu.sa

check for

updates

Citation: Khayyat, A.N.; Abbas, H.A.; Mohamed, M.F.A.; Asfour, H.Z.; Khayat, M.T.; Ibrahim, T.S.; Youns, M.; Khafagy, E.-S.; Abu Lila, A.S.; Safo, M.K.; et al. Not Only Antimicrobial: Metronidazole Mitigates the Virulence of Proteus mirabilis Isolated from Macerated Diabetic Foot Ulcer. Appl. Sci. 2021, 11, 6847. https://doi.org/10.3390/ app11156847

Academic Editor: Zimi Sawacha

Received: 28 June 2021

Accepted: 21 July 2021

Published: 26 July 2021

Publisher's Note: MDPI stays neutral with regard to jurisdictional claims in published maps and institutional affiliations.

Copyright: (c) 2021 by the authors. Licensee MDPI, Basel, Switzerland. This article is an open access article distributed under the terms and conditions of the Creative Commons Attribution (CC BY) license (https:// creativecommons.org/licenses/by/ $4.0 /)$.
5 Department of Pharmaceutical Organic Chemistry, Faculty of Pharmacy, Zagazig University, Zagazig 44519, Egypt

6 Department of Biochemistry and Molecular Biology, Faculty of Pharmacy, Helwan University, Cairo 11795, Egypt; dr.mahmoudyouns@yahoo.com

7 Department of Pharmaceutics, College of Pharmacy, Prince Sattam Bin Abdulaziz University, Al-kharj 11942, Saudi Arabia; e.khafagy@psau.edu.sa

8 Department of Pharmaceutics and Industrial Pharmacy, Faculty of Pharmacy, Suez Canal University, Ismailia 41552, Egypt

9 Department of Pharmaceutics and Industrial Pharmacy, Faculty of Pharmacy, Zagazig University, Zagazig 44519, Egypt; a.abulila@uoh.edu.sa

10 Department of Pharmaceutics, College of Pharmacy, University of Hail, Hail 81442, Saudi Arabia

11 Department of Medicinal Chemistry, School of Pharmacy, Virginia Commonwealth University, Richmond, VA 23219, USA; msafo@vcu.edu

* Correspondence: waelmhegazy@daad-alumni.de; Tel.: +20-110-118-8800

Abstract: Diabetic foot ulcers are recognized to be a severe complication of diabetes, increasing the risk of amputation and death. The bacterial infection of Diabetic foot ulcers with virulent and resistant bacteria as Proteus mirabilis greatly worsens the wound and may not be treated with conventional therapeutics. Developing new approaches to target bacterial virulence can be helpful to conquer such infections. In the current work, we evaluated the anti-virulence activities of the widely used antibacterial metronidazole. The minimum inhibitory concentrations (MIC) and minimum biofilm eradication concentrations (MEBC) were determined for selected antibiotics which P. mirabilis was resistant to them in the presence and absence of metronidazole in sub-MIC. The effect of metronidazole in sub-MIC on P. mirabilis virulence factors as production of exoenzymes, motilities, adhesion and biofilm formation, were evaluated. Furthermore, molecular docking of metronidazole into $P$. mirabilis adhesion and essential quorum sensing (QS) proteins, was performed. The results revealed a significant ability of metronidazole to in-vitro inhibit $P$. mirabilis virulence factors and antagonize its essential proteins. Moreover, metronidazole markedly decreased the MICs and MBECs of tested antibiotics. Conclusively, metronidazole in sub-MIC is a plausible anti-virulence and anti-QS agent that can be combined to other antibiotics as anti-virulence adjuvant to defeat aggressive infections.

Keywords: Proteus mirabilis; metronidazole; anti-virulence; anti-quorum sensing; diabetic foot ulcers 


\section{Introduction}

Diabetic foot ulcers are the most serious complication of diabetes mellitus and the most common lower extremity injuries that are ended by amputation. The non-traumatic amputations are mainly observed among diabetics. For instance, the rate of amputations in diabetics is 30 to 40 times higher than in non-diabetics. The diabetic foot ulceration risk is considerably high among diabetics and may reach $25 \%$; the majority will suffer from amputation within few years after first diagnosis [1]. Unfortunately, mortality rate within five years after amputation is predicted to be $40 \%$ to $70 \%$ [2]. There are several risk factors account for the increase in the incidence of diabetic foot. Neuropathy and peripheral arterial occlusive disease are considered among the major causes of diabetic foot according to epidemiological studies [3]. The management of ulcerations in diabetic foots requires a professional management emphasizing the interdisciplinary cooperation between various medical health care providers [2]. The worst could happen when minor trauma or any breakdown in the skin integrity that leads to chronic diabetic foot wounds. Neuropathy, low vascularity and compromised immunity increase the chance to the flourishment of microbial infection especially bacterial infections $[4,5]$. The diabetic foot bacterial infections are very parlous and if not controlled may spread deeper in underlying tissues and bones. The necessity to an efficient anti-bacterial therapy is mandatory to control infections in early stages and to minimize the necessity to surgical interventions in later stages. Frequently, the diabetic foot ulcers can be infected by diverse Gram-positive or -negative bacteria that are characterized by high resistance to antibiotics [2,4]. Infection with Proteus mirabilis is recognized among the most serious diabetic foot ulcers infections.

Proteus mirabilis is a motile and non-lactose fermenter member of Gram-negative Enterobacteriaceae family. To describe Proteus species shapeshifting, Hauser (1885) named it after the sea-God Proteus in Homer's Odyssey. P. mirabilis is characterized by its dimorphic short rods and elongated swarmer cells that express a lot of flagella [6]. P. mirabilis causes a broad range of pathogenesis, it causes more than $3 \%$ of all nosocomial infections and up to $44 \%$ of catheter-associated urinary tract infections [7]. P. mirabilis is one of the most serious diabetic foot ulcers infectious agents that isolated in percentage about 18\% [8-10]. The P. mirabilis virulence factors are encoded on chromosomally integrated or even extra-chromosomally imported genes [11]. Theses virulence factors are widely assorted from constitutional organelles as flagella swarming motility and adhesive fimbria to production of various extracellular enzymes and toxins as protease, urease and hemolysins [6,7]. Quorum sensing (QS) system is a signaling system to regulate the bacterial pathogenesis, QS plays crucial roles in organization of P. mirabilis infection, colonization and biofilm formation [12]. Furthermore, P. mirabilis incessantly develops a resistance to various antibiotics [13,14]. The infectious ability of $P$. mirabilis is mostly related to the biofilm formation, that constitutes an additional difficulty in treatment by conventional antibiotics $[7,12,14]$. Critically, resistance development beside biofilm formation worsens the P. mirabilis infections to diabetic foot ulcers and impede the therapeutic treatment towards favoring surgical interventions $[9,13]$.

In such aggressive bacterial infections as those in diabetic foot ulcers, it is essential to invent new strategies to guarantee an effective treatment by antibiotics. One of these strategies is crippling bacterial virulence and targeting its QS [15-18]. Without affecting the bacterial growth, this strategy decreases the possibility of the bacterial resistance development [19-21]. In this direction, several groups investigated the anti-virulence and anti-QS activities of safe naturally products or FDA approved drugs [16,17,21-27]. Metronidazole is very widely used antimicrobial mainly against most anaerobic Gram-negative and -positive bacteria and protozoans [28]. It is considered gold standard antimicrobial which all other anaerobic active antibiotics should be compared [29]. In this work, we aimed to investigate the anti-virulence activities of metronidazole on highly resistant $P$. mirabilis isolated from macerated diabetic foot ulcer. 


\section{Materials and Methods}

\subsection{Bacterial Strain and Materials}

Clinical P. mirabilis specimen was isolated from macerated incurable diabetic foot ulcers (grade 3: deep with osteitis) of an admitted female patient (62 years old) in Hospitals of Zagazig University; it was Gram stained and biochemically identified [20,30]. LuriaBertani (LB) broth and agar, Tryptone soya broth (TSB) and Mueller Hinton (MH) broth and agar were purchased from Oxoid (Hampshire, UK). The used chemicals and solvents in this study were of pharmaceutical grade. Metronidazole was ordered from Sigma-Aldrich (St. Louis, MO, USA).

The pus in the deep wound was aspirated, Gram stained and cultured on LB and MH agar and TSB broth. The isolated pure colonies were identified biochemically. The isolates were Gram-negative rods, produced yellowish lactose non-fermenting colonies on MacConkey's agar and showed significant $P$. mirabilis swarming on nutrient agar. Furthermore, the pure isolates did not ferment indole and showed black due to hydrogen sulphide production in triple sugar iron (TSI) agar.

\subsection{Minimum Inhibitory Concentration (MIC) Determination}

The MICs of antibiotics or metronidazole to P. mirabilis were detected by the microdilution in broth according to Clinical Laboratory and Standards Institute Guidelines (CLSI, 2012) [19,25]. In this assay we used antibiotics: ciprofloxacin, cefoperazone, amoxicillin/clavulinic acid, imipenem, gentamycin, tetracycline, chloramphenicol and metronidazole in concentrations ranged from $0.5 \mu \mathrm{g} / \mathrm{mL}$ to $20 \mathrm{mg} / \mathrm{mL}$. Escherichia coli ATCC 25922 was used as bacterial control. Briefly, P. mirabilis inoculum was cultivated overnight in TSB and then standardized to have a turbidity equivalent $0.5 \mathrm{McF}$ arland with MH broth. The bacterial suspensions were diluted with PBS to approximately $10^{6} \mathrm{CFU} / \mathrm{mL}$. Equal volumes of serially diluted concentrations of metronidazole or antibiotics and bacterial suspension aliquots were added to wells of 96-microtite plate and incubated at $37{ }^{\circ} \mathrm{C}$ for $24 \mathrm{~h}$. The test was conducted in triplicate and the MIC was observed as the lowest concentration that did not show turbidity in wells.

\subsection{Effect of Metronidazole in Sub-MIC on P. mirabilis Growth}

The metronidazole in sub-MIC effect on the tested P. mirabilis growth was evaluated to exclude any effect of metronidazole on the bacterial growth $[16,24,31]$. P. mirabilis overnight cultures were prepared in LB broth and adjusted to standard 0.5 McFarland. Fresh LB broth tubes with or without metronidazole ( $\frac{1}{2}$ MIC or $\frac{1}{4}$ MIC) were inoculated with P. mirabilis $\left(1 \times 10^{8} \mathrm{CFU} / \mathrm{mL}\right)$ and were overnight incubated at $37^{\circ} \mathrm{C}$. The experiment was conducted in triplicate and the broth cultures' optical densities were measured at $600 \mathrm{~nm}$.

\subsection{Protease Assay}

The production of protease was assayed in presence and absence of metronidazole using casein substrate as described previously [20,32]. Briefly, P. mirabilis overnight cultures were grown in LB broth in presence or absence of metronidazole in $\frac{1}{2}$ MIC or $\frac{1}{4}$ MIC at $37^{\circ} \mathrm{C}$ for $24 \mathrm{~h}$ and then the supernatants were collected by centrifugation. Supernatants $(1 \mathrm{~mL})$ were mixed with $1 \mathrm{~mL}$ of $2 \%$ casein in phosphate buffer $(0.05 \mathrm{M})$ and $\mathrm{NaOH}$ $(0.1 \mathrm{M})$ at $\mathrm{pH}$ 7.0. After incubation for $10 \mathrm{~min}$ at $37^{\circ} \mathrm{C}$; the reaction was stopped at room temperature by adding $0.4 \mathrm{M}$ Trichloroacetic acid $(2 \mathrm{~mL})$ for $30 \mathrm{~min}$. The precipitates were removed by centrifugation and the optical densities were detected at $660 \mathrm{~nm}$. The assays were performed triplicate and the obtained optical densities were compared in presence of metronidazole to untreated bacteria (positive control) and negative control (PBS). the protease inhibition percentage was calculated by employing the following equation:

$\frac{\text { Metronidazole }(\mathrm{sub}-\mathrm{MIC}) \text { treated or untreated P. mirabilis }- \text { Negative control }}{\text { Positive control }- \text { Negative control }} \times 100$ 


\subsection{Hemolysis Assay}

P. mirabilis isolate was overnight grown in LB broth containing or not metronidazole $\frac{1}{2}$ MIC or $\frac{1}{4}$ MIC at $37^{\circ} \mathrm{C}$. The supernatants were collected by centrifugation of bacterial suspensions for hemolysin assay $[16,23,25]$. Briefly, half $\mathrm{mL}$ of supernatants was mixed with erythrocyte suspensions ( $2 \%$ in sterile saline $(0.8 \mathrm{~mL})$, kept at $37^{\circ} \mathrm{C}$ for $2 \mathrm{~h}$ and centrifuged. The optical densities of released hemoglobin was assayed at $540 \mathrm{~nm}$. Negative control of un-hemolyzed erythrocytes and positive control of completely hemolyzed erythrocytes by adding Sodium Dodecyl Sulfate $(0.1 \%)$ were prepared in the same conditions. The assay was done in triplicate and the hemolysis inhibition percentage was evaluated by employing the following equation:

$$
\frac{\text { Metronidazole }(\mathrm{sub}-\mathrm{MIC}) \text { treated or untreated P. mirabilis }- \text { Negative control }}{\text { Positive control }- \text { Negative control }} \times 100
$$

\subsection{Urease Assay}

In order to evaluate the inhibitory effects of metronidazole on production of urease was performed as described earlier [20]. Five $\mu \mathrm{L}$ from P. mirabilis overnight cultures were impeded on the center of the Christensen's urea agar plates supplemented with metronidazole in $\frac{1}{2}$ MIC or $\frac{1}{4}$ MIC and incubated at $37^{\circ} \mathrm{C}$ for $24 \mathrm{~h}$. The color change of the $\mathrm{pH}$ indicator from yellow to pink indicates the urease activity. Control plates were prepared in the same manner; pink zones were measured in $\mathrm{mm}$. The assay was repeated triplicate and the percentages of urease inhibition was calculated:

$\frac{\text { Pink zone diameter of control }- \text { Pink zone diameter in presence of metronidazole in sub }- \text { MIC }}{\text { Pink zone diameter of control }} \times 100$

\subsection{Assay of P. mirabilis Motilities}

The inhibitory effects of metronidazole on swarming and swimming were evaluated $[15,23,25]$. Overnight $P$. mirabilis cultures were prepared and $5 \mu \mathrm{L}$ from these cultures were inoculated on the center of the dried surfaces of either LB swarming (1.5\% agar) or swimming $\left(0.4 \%\right.$ agar) plates with or without different sub-MIC of metronidazole $\left(\frac{1}{2}\right.$ MIC or $\left.\frac{1}{4} \mathrm{MIC}\right)$. After overnight incubation at $37^{\circ} \mathrm{C}$; the motility zones were measured in $\mathrm{mm}$. The test was performed triplicate and control plates without metronidazole were prepared in the same conditions. The percent of motility inhibition was calculated as:

$\frac{\text { Motility diameter of control }- \text { Motility diameter in presence of metronidazole in sub - MIC }}{\text { Motility diameter of control }} \times 100$

\subsection{Adhesion Assay}

In order to evaluate the effect of metronidazole on bacterial adhesion, $P$. mirabilis overnight cultures were prepared, diluted with fresh TSB and adjusted to a cell density of $1 \times 10^{6} \mathrm{CFU} / \mathrm{mL}$ for adhesion assay [33].

\subsubsection{Adhesion to Epithelial Cells}

Epithelial cells were obtained from urine of pregnant woman, washed and resuspended in phosphate buffer saline. Epithelial cells were counted, eventually distributed in microtiter-plate and co-cultured with P. mirabilis in total volume $200 \mu \mathrm{L}$ in presence or absence of metronidazole in concentrations $\frac{1}{2}$ MIC or $\frac{1}{4}$ MIC. After incubation for $1 \mathrm{~h}$ at $37^{\circ} \mathrm{C}$, cells were washed with PBS 3 times, fixed for $25 \mathrm{~min}$ at $60^{\circ} \mathrm{C}$, simple stained with equal volume of safranin for $45 \mathrm{~min}$ and excess day was washed out. The bacterial cells adhered to epithelial cells were counted on at least 20 epithelial cells. 


\subsubsection{Adhesion to Abiotic Surfaces}

P. mirabilis was grown with metronidazole in sub-MIC concentrations $\left(\frac{1}{2}\right.$ MIC or $\frac{1}{4} \mathrm{MIC}$ ) in microtiter-plate, incubated at $37^{\circ} \mathrm{C}$ for $1 \mathrm{~h}$, washed, fixed at $20 \mathrm{~min}$ for $60^{\circ} \mathrm{C}$, stained with crystal violet in equal volume for $20 \mathrm{~min}$ and the excess dye was washed out. Ethanol was added to extract the dye of adhered bacterial cells and optical densities were detected at $590 \mathrm{~nm}$. The experiment was performed triplicate and the percentage of adhesion inhibition was calculated:

$$
\frac{\text { OD590 of control }- \text { OD590 in presence of metronidazole in sub }- \text { MIC }}{\text { OD590 of control }} \times 100
$$

\subsection{Biofilm Formation Assay}

\subsubsection{Assessment of Biofilm Formation}

Overnight cultures of $P$. mirabilis were prepared, diluted with fresh TSB and the cell density was adjusted to $1 \times 10^{6} \mathrm{CFU} / \mathrm{mL}$ for evaluation of biofilm production $[15,25,34]$. Aliquots of the bacterial suspension $(200 \mu \mathrm{L})$ were transferred to sterile microtiter plates and incubated overnight at $37^{\circ} \mathrm{C}$. The non-adherent bacterial cells were washed out and methanol (99\%) was used to fix the adherent cells for $25 \mathrm{~min}$. The fixed cells were stained with crystal violet for $25 \mathrm{~min}$, the excess dye was washed out, the plates were dried and the bounded dye was extracted with ethanol (95\%). The experiment was conducted triplicate and the optical densities were detected at $590 \mathrm{~nm}$. The cut off OD (ODc) was calculated as 3 times standard deviation above the negative control mean OD. The isolate can be classified into one of 4 groups; strong biofilm-forming (OD $>4 \times$ ODc), moderate biofilmforming (OD $>2 \times$ ODc, but $\leq 4 \times \mathrm{ODc}$ ), weak biofilm-forming (OD $>$ ODc, but $\leq 2 \times \mathrm{ODc}$ ), or not biofilm-forming (OD $\leq$ ODc) [34].

\subsubsection{Biofilm Production Assay}

For assessment of metronidazole inhibitory effects on biofilm formation; similar steps used to assess the biofilm formation were performed. Aliquots of $P$. mirabilis suspensions $(100 \mu \mathrm{L})$ were transferred to 96 -microtitre plates containing $100 \mu \mathrm{L}$ of metronidazole $\left(\frac{1}{2}\right.$ MIC or $\frac{1}{4}$ MIC). The optical densities of the stain extracted form biofilms were detected at a wavelength of $590 \mathrm{~nm}$ in the presence or absence of metronidazole. The assay was repeated triplicate and the inhibition of biofilm formation was calculated:

$$
\frac{\text { OD590 of control }- \text { OD590 in presence of metronidazole in sub }- \text { MIC }}{\text { OD590 of control }} \times 100
$$

\subsubsection{Minimum Biofilm Eradication Concentration (MBEC) Determination}

The MBECs of the metronidazole or antibiotics were determined by broth dilution method [35]. Adjusted overnight cultures with TSB equivalent to $0.5 \mathrm{McFarland}$ standard, were transferred to the wells of microtiter plates $(100 \mu \mathrm{L})$. After incubation overnight at $37^{\circ} \mathrm{C}$, the wells were washed out and air dried. One hundred $\mu \mathrm{L}$ equivalent to 2fold dilution of metronidazole or the respective antibiotic in $\mathrm{MH}$ broth were mixed with established biofilms. The plates were incubated at $37^{\circ} \mathrm{C}$ for $20 \mathrm{~h}$, the experiment was repeated triplicate and MBEC was considered the lowest concentration that showed no turbidity in the wells.

\subsection{Combination of Metronidazole with Antibiotics}

To evaluate the outcome of combining metronidazole in sub-MIC with antibiotics, the MICs of these antibiotics were detected in the presence of metronidazole $\left(\frac{1}{4} \mathrm{MIC}\right)$. The 96-well plates were provided with $50 \mu \mathrm{L}$ of 4 -fold the final concentrations of each metronidazole and antibiotics and then cultured with adjusted bacterial inoculum $\left(5 \times 10^{6} \mathrm{CFU} / \mathrm{mL}\right)$ and overnight incubated at $37^{\circ} \mathrm{C}$. The MICs were observed and Fractional inhibitory 
concentration (FIC) of antibiotic was calculated [36]. The result of the combination: FIC $>4$ (antagonistic), FIC $>0.5$ to 4 (indifferent), or FIC $\leq 0.5$ (synergistic).

$$
\text { FIC of drug } \mathrm{A}=\frac{\text { MIC drug A in combination }}{\text { MIC drug A alone }}
$$

\subsection{Molecular Docking of Metronidazole onto P. mirabilis Proteins}

Docking analysis was performed using the Discovery Studio 2.5 software (Accelrys Inc., San Diego, CA, USA). Totally automatic docking tool using “Dock ligands (CDOCKER)" was used. The docked compounds were assembled by a software Chem 3D ultra 12.0 [Chemical Structure Drawing Standard; Cambridge Soft corporation, USA (2010)] and then the Discovery Studio 2.5 software. Procedure of automatic protein formulation was conducted through the MMFF94 forcefield with the binding site sphere recognized by the software. The receptors were defined as "input receptor molecule" in the CDOCKER protocol. Force fields were used on the tested compounds to achieve the minimum lowest energy structures. These poses were ranked and studied thoroughly, presenting the best ligand-interactions from the calculations and 2D and 3D examinations [37-39].

\subsection{Statistical Analysis}

The experiments were conducted triplicates and the results are expressed as the mean \pm standard error. The statistically significant difference between the control and metronidazole was analyzed by one-way ANOVA test (Graphpad Prism 8 software). The results were significant statistically in case of $p$ values $<0.05$.

\section{Results}

\subsection{Determination of MIC and $M B E C$}

The MICs of antibiotics or metronidazole were estimated by the broth microdilution method and the results were summarized in Table 1.

Table 1. Metronidazole and Antibiotics MIC and MBEC to P. mirabilis isolated from diabetic foot.

\begin{tabular}{cccc}
\hline Tested Agent & MIC & MBEC & Ratio MBEC/MIC \\
\hline Metronidazole & $10 \mathrm{mg} / \mathrm{mL}$ & $40 \mathrm{mg} / \mathrm{mL}$ & 4 \\
Ciprofloxacin & $2 \mu \mathrm{g} / \mathrm{mL}$ & $128 \mu \mathrm{g} / \mathrm{mL}$ & 64 \\
Cefoperazone & $64 \mu \mathrm{g} / \mathrm{mL}$ & $1024 \mu \mathrm{g} / \mathrm{mL}$ & 16 \\
Amoxicillin/Clavulinic acid & $256 \mu \mathrm{g} / \mathrm{mL}$ & $2048 \mu \mathrm{g} / \mathrm{mL}$ & 8 \\
Imipenem & $4 \mu \mathrm{g} / \mathrm{mL}$ & $8 \mu \mathrm{g} / \mathrm{mL}$ & 2 \\
Gentamycin & $16 \mu \mathrm{g} / \mathrm{mL}$ & $512 \mu \mathrm{g} / \mathrm{mL}$ & 32 \\
Tetracycline & $64 \mu \mathrm{g} / \mathrm{mL}$ & $2048 \mu \mathrm{g} / \mathrm{mL}$ & 32 \\
Chloramphenicol & $64 \mu \mathrm{g} / \mathrm{mL}$ & $2048 \mu \mathrm{g} / \mathrm{mL}$ & 32 \\
\hline
\end{tabular}

\subsection{Effect of Metronidazole in Sub-MIC on Bacterial Growth}

To confirm the absence of any effect of metronidazole in sub-MIC on the bacterial growth, the optical densities of overnight bacterial growth in precence and absence of metronidazole ( $\frac{1}{2}$ MIC or $\frac{1}{4}$ MIC) were measured at $600 \mathrm{~nm}$. No significant difference was observed between the growth of the bacterial suspensions with or without metronidazole, that means metronidaole (sub-MIC) did not affect the bacterial growth (Figure 1). 


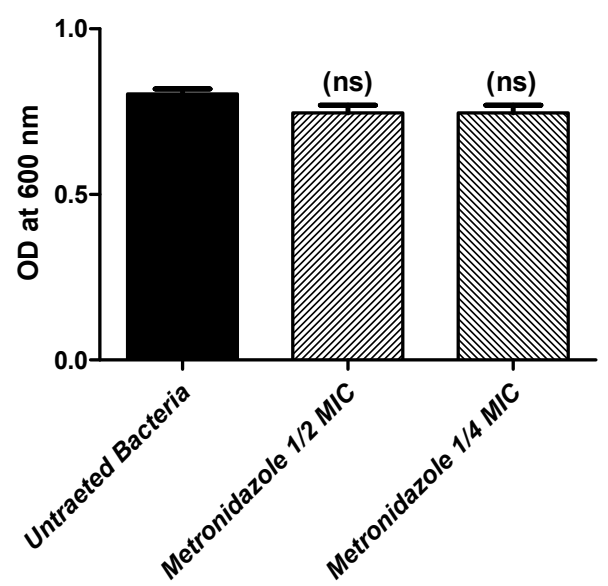

Figure 1. Effect of metronidazole in sub-MIC on P. mirabilis growth. LB broth with or without metronidazole ( $\frac{1}{2}$ MIC or $\frac{1}{4}$ MIC) was inoculated with a fresh inoculum of adjusted P. mirabilis to 0.5 McFarland Standard equivalent and the optical densities were measured after overnight culturing at $37^{\circ} \mathrm{C}$. One-Way ANOVA test was applied to compare between bacterial growth in presence and absence of metronidazole; statistical significance was assumed when $p$ values $<0.05$. There was no statistical significance between metronidazole treated and untreated cultures $(p>0.05)$.

It is worthy to confirm that we tested the effect of DMSO in the used concentration $(1.5 \%)$ on the bacterial growth and virulence and used it as control in each experiment. We did not observe any significant difference between DMSO treated cultures and untreated cultures.

\subsection{Effect of Metronidazole in Sub-MIC on Production of Bacterial Virulence Enzymes}

To evaluate the anti-virulence activities of metronidazole in sub-MIC on P. mirabilis virulence. The inhibition effect of metronidazole on production of some virulent exoenzymes were assessed. Significantly, metronidazole in sub-MIC reduced the production of protease, hemolysins and urease (Figure 2).

\subsection{Effect of Metronidazole in sub-MIC on Bacterial Motilities}

Bacterial motility is important for adhesion and biofilm formation and diminishing effect of metronidazole of bacterial motility indicate its anti-QS and anti-virulence activities. The diameters of P. mirabilis swimming and swarming were measured on LB agar $(0.4 \%$ or $1.5 \%$, respectively) plates with or without metronidazole ( $\frac{1}{2}$ MIC or $\frac{1}{4}$ MIC). Significantly, metronidazole diminished the bacterial motility (Figure 3). Moreover, light microscope images were taken for the P. mirabilis cells at the center and edge of swarming. Clearly, cells at the edge which represent the swarmer cells were larger and longer than those in the center. In the presence of metronidazole $\left(\frac{1}{2} \mathrm{MIC}\right)$, the cells at the sizes of swarmer cells were smaller than swarmer cells in absence of metronidazole (Figure 3A).

\subsection{Effect of Metronidazole in Sub-MIC on Bacterial Adhesion}

Biofilm formation and bacteria invasion are basicaly depend on the capability of bacterial cells to adhere either to living cells or inanimate objects. In order to evalute the effect of metronidazole on bacterial adhesion to cells or abiotic surfaces; P. mirabilis treated or untreated with metronidazole were cocultured with epithelial cells or in microtitre plates, repectively. Markedly, the numbers of adhered bacterial cells to epithelial cells were reduced in precence of metronidazole (Figure 4A,B). Furthermore, $P$. mirabilis treated or untreated with metronidazole ( $\frac{1}{2}$ MIC or $\frac{1}{4}$ MIC) was incubated in microtitre plate for $60 \mathrm{~min}$ and the optical denisties of atained adhered cells were measured. As metronidazole reduced the adherence of bacterial cells to epithelial cells, metronidazole significantly reduced the adhesion to abiotic surfaces (Figure 4C). 
Furthermore, the structural interaction between metronidazole and the Zn-dependent receptor-binding domain of $P$. mirabilis MR/P fimbrial adhesin $\mathrm{MrpH}$, was in-silico evaluated. The results indicated that metronidazole fit nicely into the binding site of $P$. mirabilis adhesin MrpH (PDB ID: 6Y4F) with the formation of two hydrogen bonds with Thr116 via the oxygen atom of $\mathrm{NO}_{2}$ group and $\mathrm{Arg} 118$ through the proton of $\mathrm{OH}$ group, in addition to many hydrophobic interactions with Thr116, Arg118 and Ile140. Notably, metronidazole engaged in the formation of one metal acceptor bond with ZN:201 with the oxygen atom of $\mathrm{OH}$ group (Figure 4D).

\subsection{Effect of Metronidazole in Sub-MIC on Biofilm Formation}

To evaluate the biofilm production, $P$. mirabilis was considerd according [34] as strong biofim forming when $\mathrm{OD}>4 \times \mathrm{ODc}(\mathrm{OD}=0.34$ and $\mathrm{OD}=0.064)$. The MBECs were determined and presented for the selected antibiotics and metronidazole in Table 1.
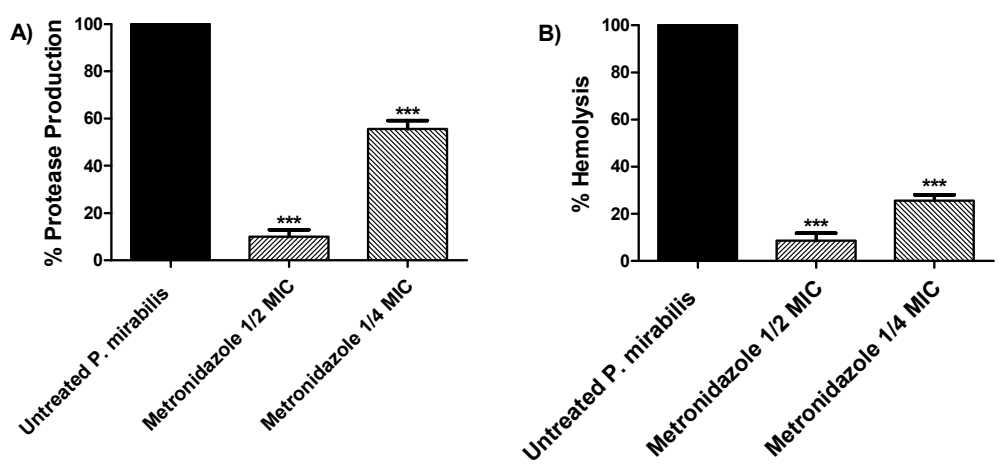

C)
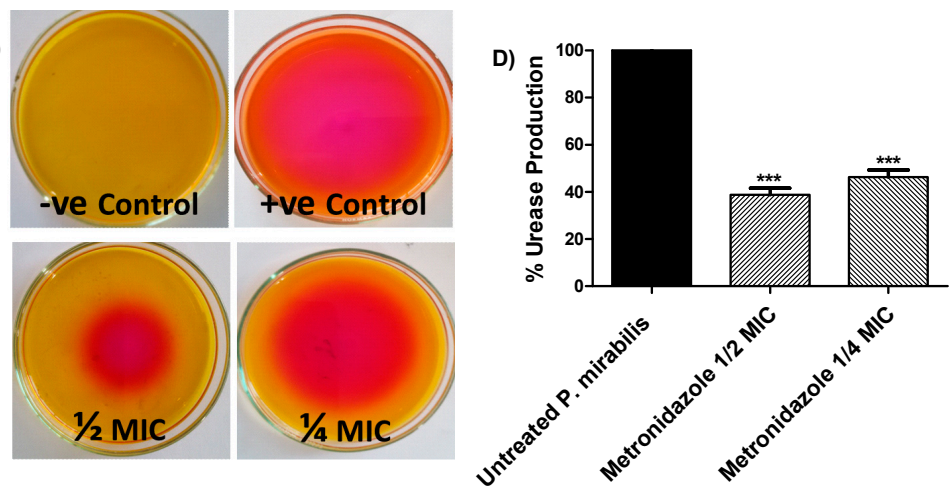

Figure 2. Effect of metronidazole in sub-MIC on P. mirabilis virulence enzymes. One-way ANOVA test was employed to compare between the metronidazole in $\frac{1}{2}$ MIC or $\frac{1}{4}$ MIC treated and untreated bacterial cultures. The data were presented as mean \pm standard error of percentage change from untreated cultures; and were considered statistically significant when $p$ values $<0.05$. (A) Protease production: significantly, metronidazole reduced the protease production in comparison to untreated cultures $(p<0.0001)$. (B) Hemolytic activity: metronidazole in sub-MIC significantly decreased the hemolytic activity $(p<0.0001)$. (C,D) Urease inhibition: Christensen's urea agar plates containing different sub-MIC of metronidazole were used. The change in the color of the $\mathrm{pH}$ indicator from yellow to pink indicates the urease activity and pink zones were measured in $\mathrm{mm}$. Metronidazole significantly reduced the production of ureases $(p<0.0001),{ }^{* * *}=p<0.001$. 


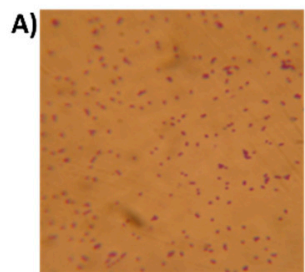

Cells at the center

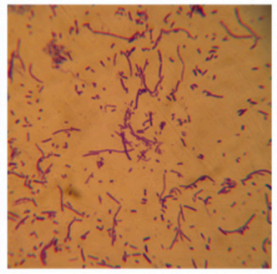

Swarmer Cells

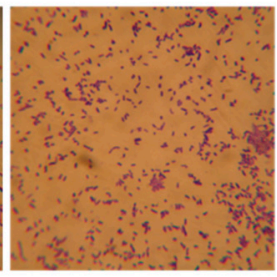

Swarmer Cells in

presence of

Metronidazole

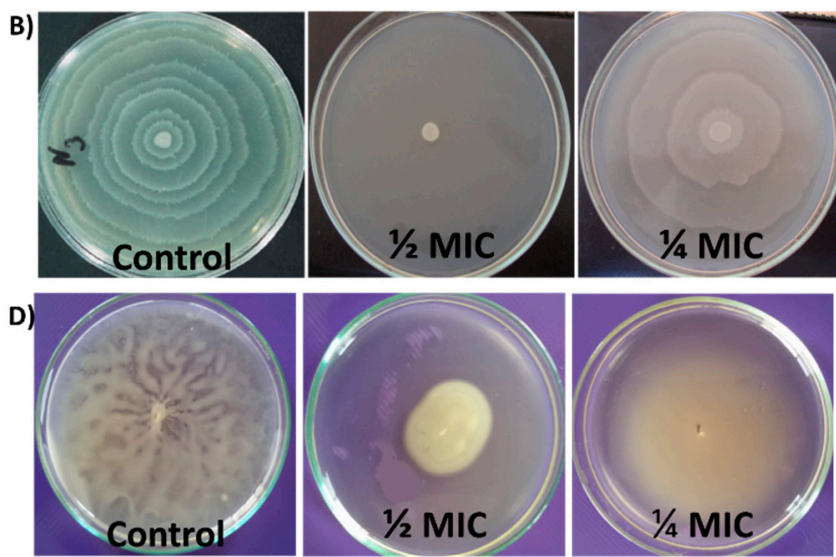

C)
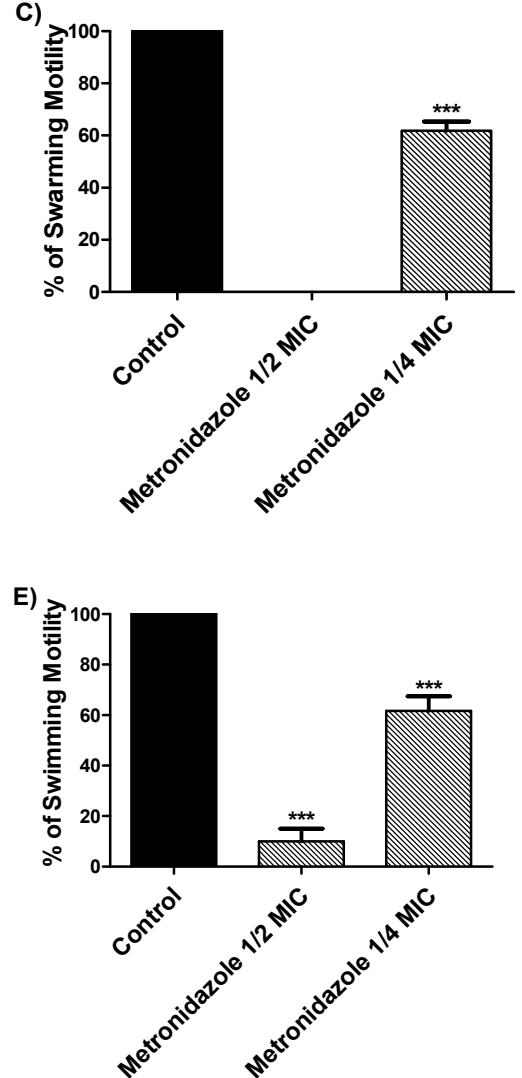

Figure 3. Effect of metronidazole in sub-MIC on P. mirabilis motility. One-way ANOVA test was used to compare between the metronidazole in $\frac{1}{2}$ MIC or $\frac{1}{4}$ MIC treated and untreated bacterial cultures. The data were shown as mean \pm standard error of percentage change from untreated cultures; and were considered statistically significant when $p$ values $<0.05$. (A) Light microscope image of simple stained P. mirabilis at the center (non-swarmer cells), the edge of swarming (elongated larger swarmer cells) and swarmer cells in precence of metronidazole. Clearly, the swarmer cells in precence of metronidazole is smaller than those in absence of metronidazole. (B,C) Metronidazole in sub-MIC significantly reduced the swarming motility $(p<0.0001)$. (D,E) The diameters of swimming motiliy were significantly decreased in precence of meetonidazole in sub-MIC $(p<0.0001) .{ }^{* * *}=p<0.001$.

In order to evaluate the metronidazole inhbitory effect on biofilm production; P. mirabilis treated or untreated with metronidazole $\left(\frac{1}{2} \mathrm{MIC}\right.$ or $\left.\frac{1}{4} \mathrm{MIC}\right)$ was cultured in microtite plate overnight at $37^{\circ} \mathrm{C}$. In addition, the biofilm forming bacterial cells were crystal violet stained and optical densities were measured. Significantly, metronidazole prevented the biofilm formation (Figure 5).

\subsection{In-Silico Docking of Metronidazole into P. mirabilis QS Eseential Proteins}

To give a hint into the capability of metronidazole to antagonize the QS essential proteins; the interaction between metronidazole and QS proteins was evaluated. P. mirabilis QS protein was retrieved from UniProtKB (PMI1345) and molecular docking was carried out. The results showenin Figure 6, displayed that thereceptor well accommodating metronidazole inside the binding cavity and establishing appropriate interactions involved the formation of three hydrogen bonds; the proton of $\mathrm{OH}$ group engaged in one hydrogen bond with Glu57. The oxygen atom of $\mathrm{NO}_{2}$ involved in the formation of two hydrogen bonds with Gly129 and Thr130 amino acid residues. Additionally, the oxygen of OH group and the oxygen of $\mathrm{NO}_{2}$ group of metronidazole engaged in the formation of two important metal acceptor bonds with ZN:1. Moreover, metronidazole incorporated in many hydrophobic interactions with His54, Glu57, Cys128 and ZN:1. These results may explain the possible reasons for enhanced anti-QS activity of metronidazole. 
A)

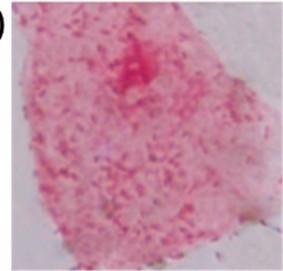

Control

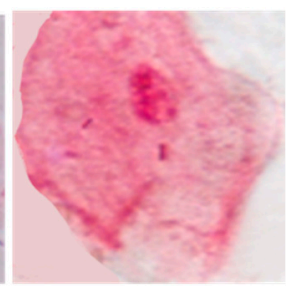

$1 / 2$ MIC
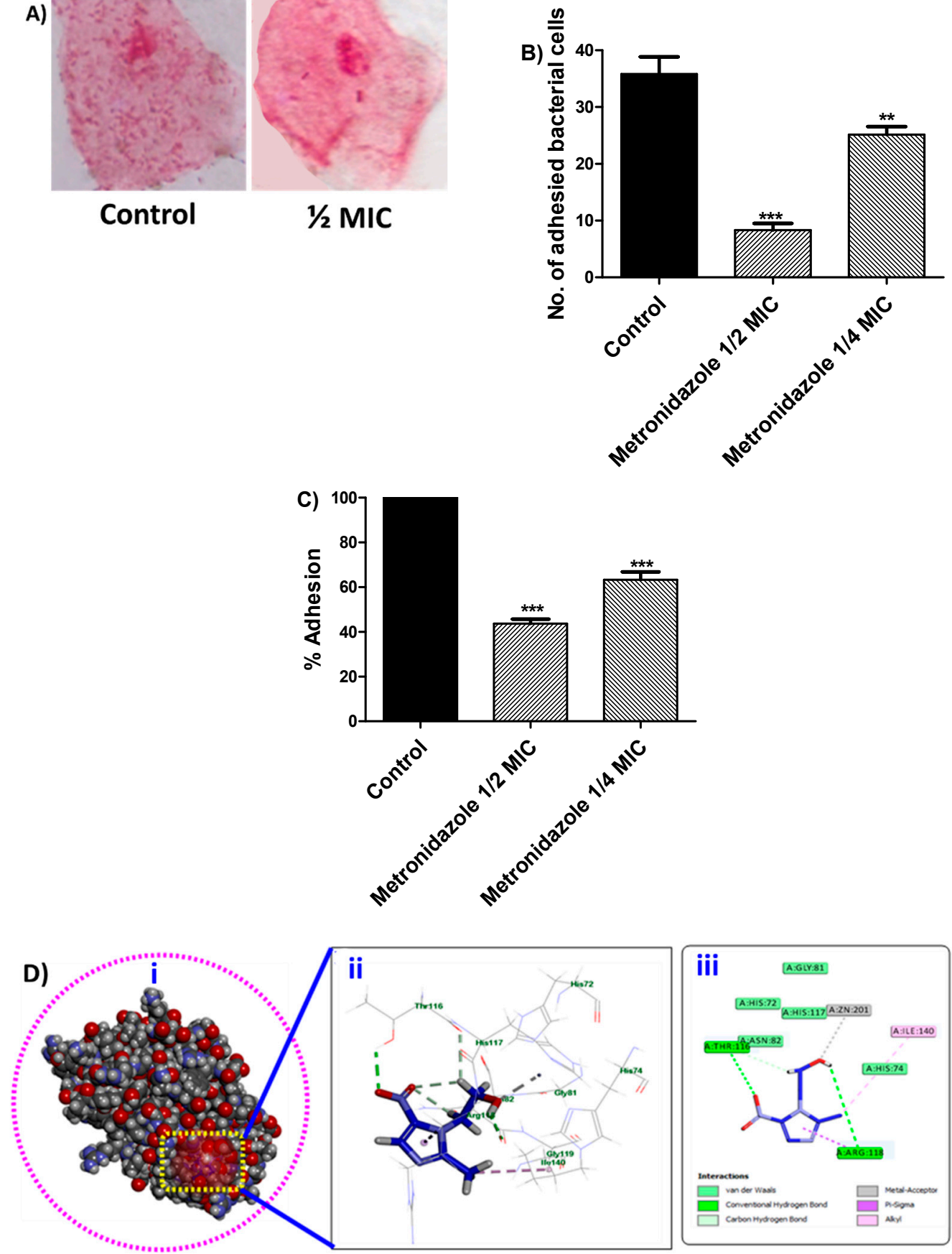

Figure 4. Effect of metronidazole in sub-MIC on P. mirabilis adhesion. (A) Adhesion to epithelial cells: epithelial cells from urine of pregnant were cocultured with $P$. mirabilis treated or untreated with metronidazole in $\frac{1}{2}$ MIC or $\frac{1}{4}$ MIC. (B) Metronidazole significantly reduced the number of adhered bacterial cells to epithelial cells $(p<0.0001$ and 0.0095 for $\frac{1}{2}$ MIC or $\frac{1}{4}$ MIC, respectively). (C) Adhesion to abiotic surface: P. mirabilis was cultured in presence or absence of metronidazole in $\frac{1}{2} \mathrm{MIC}$ or $\frac{1}{4} \mathrm{MIC}$, incubated at $37{ }^{\circ} \mathrm{C}$ for $60 \mathrm{~min}$. The adhered cells were crystal violet stained and their optical densities were measured at $590 \mathrm{~nm}$. Significantly, metronidazole reduced the bacterial adhesion $(p<0.0001)$. One-way ANOVA test was used to compare between the metronidazole in $\frac{1}{2}$ MIC or $\frac{1}{4}$ MIC treated and untreated bacterial cultures. The data were expressed as mean \pm standard error of percentage change from untreated cultures; and were considered statistically significant when $p$ values $<0.05$. (D) Interactions of metronidazole into the active site of $P$. mirabilis adhesin MrpH (PDB: ID 6Y4F): (i,ii) three dimensional and (iii) two dimensional interactions. ${ }^{* *}=p<0.01,{ }^{* * *}=p<0.001$. 


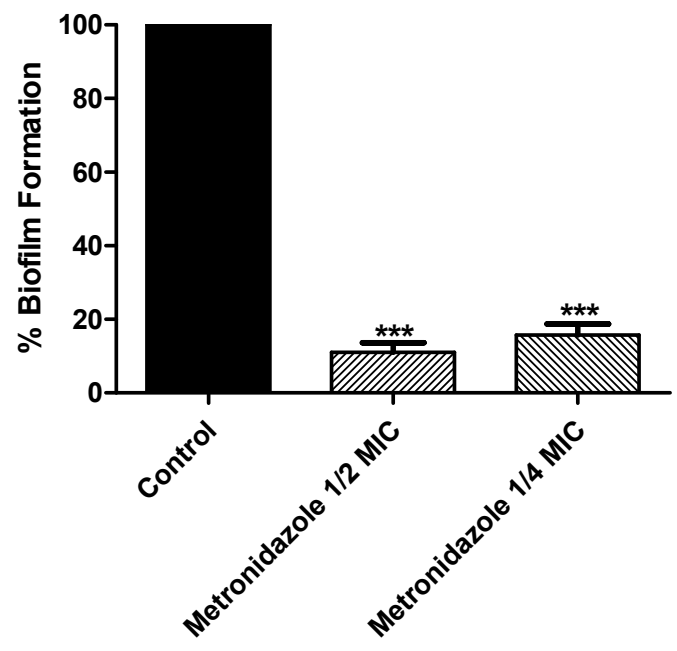

Figure 5. Effect of metronidazole in sub-MIC on biofilm formation. P. mirabilis cultures were grown in presence or absence of metronidazole ( $\frac{1}{2}$ MIC or $\left.\frac{1}{4} \mathrm{MIC}\right)$ and incubated overnight at $37^{\circ} \mathrm{C}$. The optical densities of stained adhered cells were measured at $590 \mathrm{~nm}$. Significantly, metronidazole diminished the biofilm formation $(p<0.0001)$. One-way ANOVA test was used to compare between the metronidazole in $\frac{1}{2}$ MIC or $\frac{1}{4}$ MIC treated and untreated bacterial cultures. The data were presented as mean \pm standard error of percentage change from untreated cultures; and and statistical significance was considered when $p$ values $<0.05,{ }^{* * *}=p<0.001$.

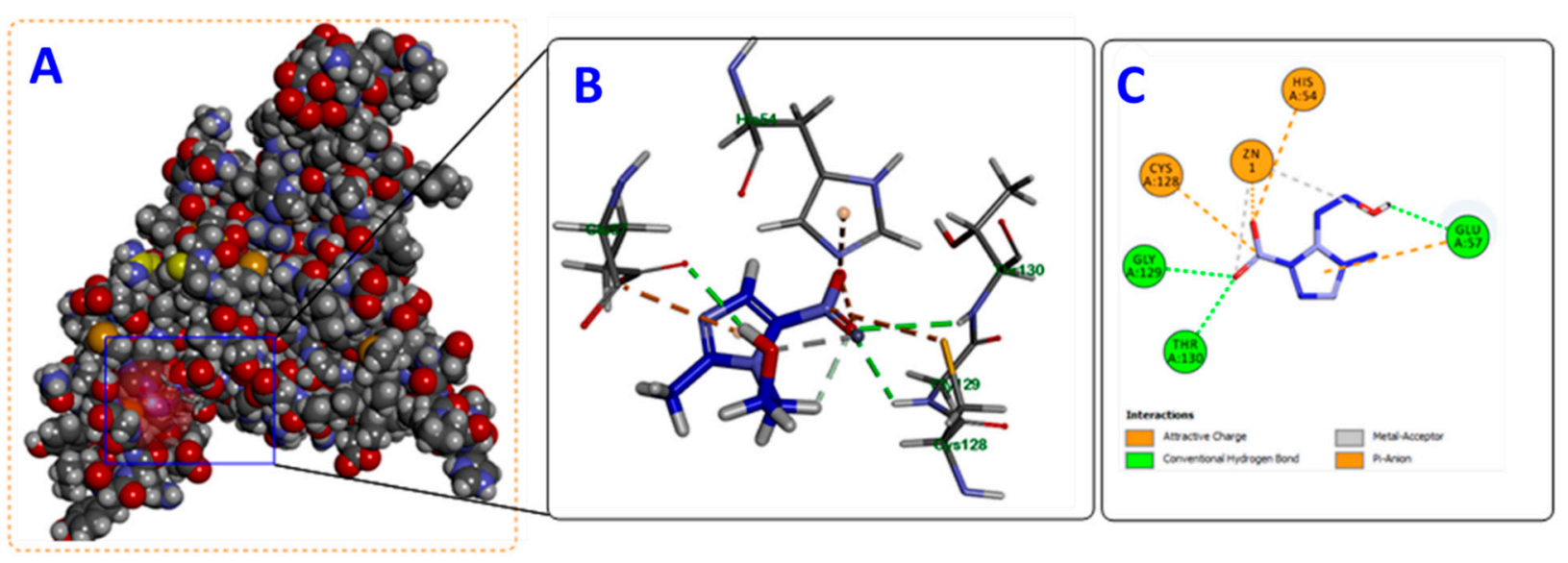

Figure 6. Interactions of metronidazole into the active site of P. mirabilis QS protein (PMI1345). (A,B) three dimensional and (C) two dimensional.

\subsection{MICs and MBECs of Tested Antibiotics in Precence of Metronidazole in Sub-MIC}

To evalutae the effect of metronidazole in sub-MIC as anti-virulence agent on decreasing of MICs and MIBCs of selected antibiotics; the MICs and MIBCs of comined metronidazole and selected antibiotics were determined. The outcomes of the combined effect of netronidazole ( $\left.\frac{1}{4} \mathrm{MIC}\right)$ and selected antibiotics were calculated according [36]. The results were summarized in Table 2. Obviously, metronidazole decreased the MICs and MIBCs of antibiotics and showed considerable synergism. 
Table 2. The susceptibility of isolated P. mirabilis to antibiotics in presence of Metronidazole ( $\frac{1}{4}$ MIC).

\begin{tabular}{ccccccc}
\hline Antibiotic & MIC & MIC $_{\text {met }}$ & FIC & MBEC & MBEC $_{\text {met }}$ & FIC \\
\hline Ciprofloxacin & $2 \mu \mathrm{g} / \mathrm{mL}$ & $1 \mu \mathrm{g} / \mathrm{mL}$ & 0.5 & $128 \mu \mathrm{g} / \mathrm{mL}$ & $32 \mu \mathrm{g} / \mathrm{mL}$ & 0.25 \\
Cefoperazone & $64 \mu \mathrm{g} / \mathrm{mL}$ & $16 \mu \mathrm{g} / \mathrm{mL}$ & 0.25 & $1024 \mu \mathrm{g} / \mathrm{mL}$ & $256 \mu \mathrm{g} / \mathrm{mL}$ & 0.25 \\
Amoxicillin/Clavulinic & $256 \mu \mathrm{g} / \mathrm{mL}$ & $32 \mu \mathrm{g} / \mathrm{mL}$ & 0.125 & $2048 \mu \mathrm{g} / \mathrm{mL}$ & $512 \mu \mathrm{g} / \mathrm{mL}$ & 0.25 \\
acid & $4 \mu \mathrm{g} / \mathrm{mL}$ & $2 \mu \mathrm{g} / \mathrm{mL}$ & 0.5 & $8 \mu \mathrm{g} / \mathrm{mL}$ & $4 \mu \mathrm{g} / \mathrm{mL}$ & 0.5 \\
Imipenem & $16 \mu \mathrm{g} / \mathrm{mL}$ & $16 \mu \mathrm{g} / \mathrm{mL}$ & 1 & $512 \mu \mathrm{g} / \mathrm{mL}$ & $256 \mu \mathrm{g} / \mathrm{mL}$ & 0.5 \\
Gentamycin & $64 \mu \mathrm{g} / \mathrm{mL}$ & $64 \mu \mathrm{g} / \mathrm{mL}$ & 1 & $2048 \mu \mathrm{g} / \mathrm{mL}$ & $1024 \mu \mathrm{g} / \mathrm{mL}$ & 0.5 \\
Tetracycline & $64 \mu \mathrm{g} / \mathrm{mL}$ & $16 \mu \mathrm{g} / \mathrm{mL}$ & 0.25 & $2048 \mu \mathrm{g} / \mathrm{mL}$ & $256 \mu \mathrm{g} / \mathrm{mL}$ & 0.125 \\
Chloramphenicol & &
\end{tabular}

MIC and MBEC: Minimum eradication concentration and minimum biofilm inhibitory concentration of tested antibiotics. MIC met and $\mathrm{MBEC}_{\text {met }}$ : Minimum inhibitory concentration and minimum biofilm eradication concentration of tested antibiotics in presence of metronidazole in concentration of $\frac{1}{4}$ MIC. FIC: Fractional inhibitory concentration $=$ MIC drug in combination/MIC drug alone. The result of the combination may be antagonistic (FIC $>4$ ), indifferent (FIC $>0.5$ to 4 ), or synergistic (FIC $\leq 0.5$ ).

\section{Discussion}

P. mirabilis causes a wide range of infections and its spread is owed to an inherent translocation capability using peritrichous flagellar. Moreover, P. mirabilis harbors a considered arsenal of exoenzymes as urease, protease and hemolysins and strong biofilm formation capability $[6,40]$. In the current study, we aimed to evaluate the effects of metronidazole on bacterial pathogenesis by challenging the virulence of highly resistant P. mirabilis isolated from diabetic foot ulcers. Metronidazole is the most globally used nitroimidazole antimicrobial agent, it is usually prescribed to anaerobic infection and is considered as gold standard which all other anaerobic acting antibiotics should be referenced [28,29]. Metronidazole interacts with bacterial DNA and consequently inhibits the bacterial protein synthesis. Metronidazole has activity on wide range of bacteria and its use possess several advantages as good tissue penetration, rapid bacterial killing and low cost [29].

In order to evaluate the effect of metronidazole on P. mirabilis virulence, we used metronidazole in sub-MICs to avoid any effect on bacterial growth. In a previous work, metronidazole and secnidazole which harbor similar chemical moiety were efficiently able to curtail the Pseudomonas aeruginosa pathogenesis [41,42]. Obviously, metronidazole has no influence at all on the bacterial growth. The proteolytic enzyme protease cleaves various essential proteins as casein, secretory components, serum albumin and gelatin. Furthermore, protease is able to breakdown 2 classes of immunoglobulins $A$ and $G$ which facilitate the spread of microbial infection and lowering the defense of the host $[43,44]$. Urease enzyme is a significant virulence factor that is used by pathogens of urinary and gastrointestinal tracts as P. mirabilis. While the production of urease is constitutive in most strains of $P$. mirabilis, it is inducible in some strains by $\mathrm{pH}$ changes $[6,44,45]$. Its capability to recycle the nitrogenous compounds enhances the resistance to several biocides [43,45]. Importantly, the degraded urea due to urease provides an alkaline optimal condition for protease action and in turn increase the microbial spread and increase the production of both urease and protease in repeated cycles $[6,46]$. The cytotoxicity of hemolysin that is encoded by 2-component secretion system $h p m$ BA genes greatly enhance P. mirabilis pathogenesis $[6,47]$. These three enzymes, protease, hemolysins and urease play crucial roles in the spread of bacterial infection especially in lack of efficient immunity as in diabetic foot ulcers $[10,20]$. Significantly, metronidazole in sub-MIC reduced the production of $P$. mirabilis exoenzymes protease, urease and hemolysins.

The $P$. mirabilis invading ability to epithelial cells is fundamentally owed to swarmer cells but not vegetative cells $[6,44]$. Flagellum dependent $P$. mirabilis motilities (swarming and swimming) facilitate the spread of infection and formation of biofilms [7,48]. Moreover, the formation of hyperflagellated swarmer cells is linked to significant increases in the production of other virulence factors as protease and urease $[45,49]$. It was suggested a close correlation between biofilm formation and bacterial motility; as the formation of biofilms is decreased in the non-motile bacteria [8]. As a consequence, the bacterial biofilm formation capability beside its motility result in spreading of infection and enhancing of 
antibiotic resistance of the persistent microbes in diabetic foot ulcers [10]. Our findings revealed a significant diminishing effect of metronidazole on P. mirabilis motilities.

Biofilm formation is characteristic feature of the life style of pathogenic bacteria; It is composed of embedded microbial cells in dynamic communities that accumulate either on abiotic or living surfaces $[50,51]$. In sequential manner and after bacterial adhesion to surfaces, free floating vegetative cells start to produce extracellular polymeric substances which leads to irreversible attachment and entrapping of bacteria in biofilms [52]. The flagella-driven motilities are needed for $P$. mirabilis adhesion, which followed by its colonization and biofilm formation $[49,53,54]$. In compliance with our previous findings that showed the inhibition effect of metronidazole on P. mirabilis motilities; metronidazole is significantly reduced the adhesion of $P$. mirabilis to both abiotic surfaces and epithelial cells and also significantly decreased the biofilm formation. Moreover, MICs and MBECs for the tested antibiotics were markedly lowered when combined with metronidazole $\left(\frac{1}{4}\right.$ MIC). The synergistic effect of metronidazole at sub-MIC when combined with tested antibiotics indicate that these antibiotics can be used to treat diabetic foot ulcers in lower concentration, which may decrease the side effects, the resistance development and costs.

Molecular docking is one of the most widely applied approaches for the study of protein-ligand interactions and for drug discovery and development. Therefore, molecular docking studies were carried out to get structural insights into the interaction between metronidazole and P. mirabilis QS proteins and the Zn-dependent receptor-binding domain of P. mirabilis MR/P fimbrial adhesin MrpH. Mannose Resistant Proteus like fimbriae (MRP) that are encoded by mrpABCDEFGHJ operon, are the most widely studied P. mirabilis fimbriae. MRP fimbriae are greatly essential for $P$. mirabilis aggregation, biofilm formation and colonization in kidney and bladder $[55,56]$. $\mathrm{MrpH}$ is one of the main virulence involved fimbrial proteins in P. mirabilis [56]. In this study, we showed that metronidazole has a considerable affinity to the binding site of $P$. mirabilis adhesin $\mathrm{MrpH}$. The molecular docking results emphasize our earlier finding in which we observed the reduction of adhesion in presence of metronidazole. QS is signaling system which organize the bacterial pathogenesis and QS targeting is one of the efficient approaches to diminish microbial virulence $[16,17,23]$. We hypothesized that hindering of metronidazole to QS system and bacterial adhesion leads to diminishing of the P. mirabilis virulence factors armory and help greatly in treating aggressive infections as diabetic foot ulcers. In this context, we examined the capability of metronidazole to antagonize the P. mirabilis QS essential proteins. One of the most crucial role players in P. mirabilis QS, is protein PMI1345 as it catalyzes the transfer of the phosphoribosyl group of 5-phosphorylribose-1-pyrophosphate to anthranilate to yield N-(5'-phosphoribosyl)-anthranilate [57]. While LuxS and MtnN proteins are involved in the biosynthesis of autoiducers-2; PMI1345 and MnmC proteins are involved in the translocation machinery in the QS system [58]. Essentially, Pawar et al., analysis revealed PMI1345 to be the prominent Eigenvector centrality protein in the 139th core of the $P$. mirabilis genome [57]. Our molecular docking study showed the ability of metronidazole to antagonize the essential QS protein PMI1345. Although more detailed molecular and in-vivo investigations are needs, these findings give a preliminary expectation about the metronidazole ability to hinder the QS system. It needs further pharmacological and pharmaceutical studies to validate the application of metronidazole as anti-virulence agent beside its antimicrobial activities.

\section{Conclusions}

Diabetic foot ulcers infections are among the most wretched clinical conditions, especially if the infection was with tenacious microbe as P. mirabilis. In the current study, we evaluated the anti-virulence activities of one of the most globally used antibacterial metronidazole. Our results revealed the inhibitory effectiveness of metronidazole in subMIC concentrations to various $P$. mirabilis virulence factors. Here, we introducing a new primary insight about the use of metronidazole as an anti-virulence and anti-QS agent that could be attractive for researchers and clinicians to further in-vivo investigations. 
Author Contributions: Conceptualization, W.A.H.H. and H.A.A.; methodology, H.A.A., W.A.H.H. and M.F.A.M.; software, M.F.A.M. and T.S.I.; validation, A.N.K., M.T.K. and H.Z.A.; formal analysis, A.S.A.L. and E.-S.K.; investigation, A.N.K.; resources, A.N.K., M.T.K. and H.Z.A.; data curation, A.N.K., M.T.K. and H.Z.A.; writing-original draft preparation, W.A.H.H. and H.A.A.; writingreview and editing, W.A.H.H. and M.F.A.M.; visualization, M.Y.; M.K.S. and T.S.I.; supervision, A.N.K. and W.A.H.H.; project administration, W.A.H.H.; funding acquisition, M.T.K., H.Z.A., M.K.S. and A.N.K. All authors have read and agreed to the published version of the manuscript.

Funding: The Deanship of Scientific Research (DSR) at King Abdulaziz University, Jeddah, Saudi Arabia has funded this project, under grant No. (RG-16-166-42).

Informed Consent Statement: This study does not include any studies with human participants.

Conflicts of Interest: The authors declare no conflict of interest.

\section{References}

1. Van Battum, P.; Schaper, N.; Prompers, L.; Apelqvist, J.; Jude, E.; Piaggesi, A.; Bakker, K.; Edmonds, M.; Holstein, P.; Jirkovska, A.; et al. Differences in minor amputation rate in diabetic foot disease throughout Europe are in part explained by differences in disease severity at presentation. Diabet. Med. 2011, 28, 199-205. [CrossRef] [PubMed]

2. Volmer-Thole, M.; Lobmann, R. Neuropathy and Diabetic Foot Syndrome. Int. J. Mol. Sci. 2016, 17, 917. [CrossRef] [PubMed]

3. Boulton, A.J. The pathway to foot ulceration in diabetes. Med. Clin. N. Am. 2013, 97, 775-790. [CrossRef] [PubMed]

4. Hartemann-Heurtier, A.; Senneville, E. Diabetic foot osteomyelitis. Diabetes Metab. 2008, 34, 87-95. [CrossRef]

5. Hegazy, W.A.H. Hepatitis C virus pathogenesis: Serum IL-33 level indicates liver damage. Afr. J. Microbiol. Res. 2015, 9, 1386-1393. [CrossRef]

6. Armbruster, C.E.; Mobley, H.L. Merging mythology and morphology: The multifaceted lifestyle of Proteus mirabilis. Nat. Rev. Microbiol. 2012, 10, 743-754. [CrossRef]

7. Jacobsen, S.M.; Stickler, D.J.; Mobley, H.L.; Shirtliff, M.E. Complicated catheter-associated urinary tract infections due to Escherichia coli and Proteus mirabilis. Clin. Microbiol. Rev. 2008, 21, 26-59. [CrossRef]

8. Sekhar, S.; Vyas, N.; Unnikrishnan, M.; Rodrigues, G.; Mukhopadhyay, C. Antimicrobial susceptibility pattern in diabetic foot ulcer: A pilot study. Ann. Med. Health Sci. Res. 2014, 4, 742-745. [CrossRef]

9. Perim, M.C.; Borges Jda, C.; Celeste, S.R.; Orsolin Ede, F.; Mendes, R.R.; Mendes, G.O.; Ferreira, R.L.; Carreiro, S.C.; Pranchevicius, M.C. Aerobic bacterial profile and antibiotic resistance in patients with diabetic foot infections. Rev. Soc. Bras. Med. Trop. 2015, 48, 546-554. [CrossRef]

10. El-Tahawy, A.T. Bacteriology of diabetic foot. Saudi Med. J. 2000, 21, 344-347.

11. Flannery, E.L.; Mody, L.; Mobley, H.L. Identification of a modular pathogenicity island that is widespread among ureaseproducing uropathogens and shares features with a diverse group of mobile elements. Infect. Immun. 2009, 77, 4887-4894. [CrossRef]

12. Wasfi, R.; Hamed, S.M.; Amer, M.A.; Fahmy, L.I. Proteus mirabilis Biofilm: Development and Therapeutic Strategies. Front. Cell Infect. Microbiol. 2020, 10, 414. [CrossRef]

13. Tansarli, G.S.; Athanasiou, S.; Falagas, M.E. Evaluation of antimicrobial susceptibility of Enterobacteriaceae causing urinary tract infections in Africa. Antimicrob. Agents Chemother. 2013, 57, 3628-3639. [CrossRef]

14. Zhao, W.H.; Hu, Z.Q. Epidemiology and genetics of CTX-M extended-spectrum beta-lactamases in Gram-negative bacteria. Crit. Rev. Microbiol. 2013, 39, 79-101. [CrossRef]

15. Abbas, H.A.; Hegazy, W.A.H. Targeting the virulence factors of Serratia marcescens by ambroxol. Roum. Arch. Microbiol. Immunol. 2017, 76, 27-32.

16. Abbas, H.A.; Hegazy, W.A.H. Repurposing anti-diabetic drug "Sitagliptin" as a novel virulence attenuating agent in Serratia marcescens. PLoS ONE 2020, 15, e0231625. [CrossRef] [PubMed]

17. El-Hamid, A.; Marwa, I.; Y El-Naenaeey, E.S.; Hegazy, W.A.; Mosbah, R.A.; Nassar, M.S.; Bakhrebah, M.A.; Abdulaal, W.H.; Alhakamy, N.A.; Bendary, M.M. Promising Antibiofilm Agents: Recent Breakthrough against Biofilm Producing MethicillinResistant Staphylococcus aureus. Antibiotics 2020, 9, 667. [CrossRef] [PubMed]

18. Al Saqr, A.; Khafagy, E.S.; Alalaiwe, A.; Aldawsari, M.F.; Alshahrani, S.M.; Anwer, M.K.; Khan, S.; Lila, A.S.A.; Arab, H.H.; Hegazy, W.A.H. Synthesis of Gold Nanoparticles by Using Green Machinery: Characterization and In Vitro Toxicity. Nanomaterials 2021, 11, 808. [CrossRef] [PubMed]

19. Askoura, M.; Hegazy, W.A.H. Ciprofloxacin interferes with Salmonella Typhimurium intracellular survival and host virulence through repression of Salmonella pathogenicity island-2 (SPI-2) genes expression. Pathog. Dis. 2020, 78. [CrossRef]

20. Hegazy, W.A.H. Diclofenac inhibits virulence of Proteus mirabilis isolated from diabetic foot ulcer. Afr. J. Microbiol. Res. 2016, 10, 733-743. [CrossRef]

21. Hegazy, W.A.H.; Al Mamari, R.; Almazroui, K.; Al Habsi, A.; Kamona, A.; AlHarthi, H.; Al Lawati, A.I.; AlHusaini, A.H. Retrospective Study of Bone-TB in Oman: 2002-2019. J. Epidemiol. Glob. Health 2021, 11, 238-245. [CrossRef] 
22. Bendary, M.M.; Ibrahim, D.; Mosbah, R.A.; Mosallam, F.; Hegazy, W.A.H.; Awad, N.F.S.; Alshareef, W.A.; Alomar, S.Y.; Zaitone, S.A.; Abd El-Hamid, M.I. Thymol Nanoemulsion: A New Therapeutic Option for Extensively Drug Resistant Foodborne Pathogens. Antibiotics 2020, 10, 25. [CrossRef]

23. Hegazy, W.A.H.; Khayat, M.T.; Ibrahim, T.S.; Nassar, M.S.; Bakhrebah, M.A.; Abdulaal, W.H.; Alhakamy, N.A.; Bendary, M.M. Repurposing Anti-diabetic Drugs to Cripple Quorum Sensing in Pseudomonas aeruginosa. Microorganisms 2020, 8, 1285. [CrossRef]

24. Hegazy, W.A.H.; Khayat, M.T.; Ibrahim, T.S.; Youns, M.; Mosbah, R.; Soliman, W.E. Repurposing of antidiabetics as Serratia marcescens virulence inhibitors. Braz. J. Microbiol. 2021, 52, 627-638. [CrossRef] [PubMed]

25. Khayyat, A.N.; Hegazy, W.A.H.; Shaldam, M.A.; Mosbah, R.; Almalki, A.J.; Ibrahim, T.S.; Khayat, M.T.; Khafagy, E.S.; Soliman, W.E.; Abbas, H.A. Xylitol Inhibits Growth and Blocks Virulence in Serratia marcescens. Microorganisms 2021, 9, 1083. [CrossRef] [PubMed]

26. Vishwa, B.; Moin, A.; Gowda, D.V.; Rizvi, S.M.D.; Hegazy, W.A.H.; Abu Lila, A.S.; Khafagy, E.S.; Allam, A.N. Pulmonary Targeting of Inhalable Moxifloxacin Microspheres for Effective Management of Tuberculosis. Pharmaceutics 2021, 13, 79. [CrossRef]

27. Aldawsari, M.F.; Alalaiwe, A.; Khafagy, E.S.; Al Saqr, A.; Alshahrani, S.M.; Alsulays, B.B.; Alshehri, S.; Abu Lila, A.S.; Danish Rizvi, S.M.; Hegazy, W.A.H. Efficacy of SPG-ODN 1826 Nanovehicles in Inducing M1 Phenotype through TLR-9 Activation in Murine Alveolar J774A.1 Cells: Plausible Nano-Immunotherapy for Lung Carcinoma. Int. J. Mol. Sci. 2021, $22,6833$. [CrossRef]

28. Freeman, C.D.; Klutman, N.E.; Lamp, K.C. Metronidazole. A therapeutic review and update. Drugs 1997, 54, 679-708. [CrossRef] [PubMed]

29. Dingsdag, S.A.; Hunter, N. Metronidazole: An update on metabolism, structure-cytotoxicity and resistance mechanisms. J. Antimicrob. Chemother. 2018, 73, 265-279. [CrossRef]

30. Pearson, M.M. Culture Methods for Proteus mirabilis. Methods Mol. Biol. 2019, 2021, 5-13. [CrossRef]

31. Nalca, Y.; Jansch, L.; Bredenbruch, F.; Geffers, R.; Buer, J.; Haussler, S. Quorum-sensing antagonistic activities of azithromycin in Pseudomonas aeruginosa PAO1: A global approach. Antimicrob. Agents Chemother. 2006, 50, 1680-1688. [CrossRef] [PubMed]

32. Zhang, X.; Shuai, Y.; Tao, H.; Li, C.; He, L. Novel Method for the Quantitative Analysis of Protease Activity: The Casein Plate Method and Its Applications. ACS Omega 2021, 6, 3675-3680. [CrossRef] [PubMed]

33. Vesterlund, S.; Paltta, J.; Karp, M.; Ouwehand, A.C. Measurement of bacterial adhesion-in vitro evaluation of different methods. J. Microbiol. Methods 2005, 60, 225-233. [CrossRef] [PubMed]

34. Stepanovic, S.; Vukovic, D.; Dakic, I.; Savic, B.; Svabic-Vlahovic, M. A modified microtiter-plate test for quantification of staphylococcal biofilm formation. J. Microbiol. Methods 2000, 40, 175-179. [CrossRef]

35. Cernohorska, L.; Votava, M. Antibiotic synergy against biofilm-forming Pseudomonas aeruginosa. Folia Microbiol. 2008, 53, 57-60. [CrossRef]

36. Mackay, M.L.; Milne, K.; Gould, I.M. Comparison of methods for assessing synergic antibiotic interactions. Int. J. Antimicrob. Agents 2000, 15, 125-129. [CrossRef]

37. Abou-Zied, H.A.; Youssif, B.G.M.; Mohamed, M.F.A.; Hayallah, A.M.; Abdel-Aziz, M. EGFR inhibitors and apoptotic inducers: Design, synthesis, anticancer activity and docking studies of novel xanthine derivatives carrying chalcone moiety as hybrid molecules. Bioorg. Chem. 2019, 89, 102997. [CrossRef]

38. Al-Sanea, M.M.; Gotina, L.; Mohamed, M.F.; Grace Thomas Parambi, D.; Gomaa, H.A.M.; Mathew, B.; Youssif, B.G.M.; Alharbi, K.S.; Elsayed, Z.M.; Abdelgawad, M.A.; et al. Design, Synthesis and Biological Evaluation of New HDAC1 and HDAC2 Inhibitors Endowed with Ligustrazine as a Novel Cap Moiety. Drug Des. Dev. 2020, 14, 497-508. [CrossRef] [PubMed]

39. Youssif, B.G.M.; Mohamed, M.F.A.; Al-Sanea, M.M.; Moustafa, A.H.; Abdelhamid, A.A.; Gomaa, H.A.M. Novel aryl carboximidamide and 3-aryl-1,2,4-oxadiazole analogues of naproxen as dual selective COX-2/15-LOX inhibitors: Design, synthesis and docking studies. Bioorg. Chem. 2019, 85, 577-584. [CrossRef]

40. Morgenstein, R.M.; Szostek, B.; Rather, P.N. Regulation of gene expression during swarmer cell differentiation in Proteus mirabilis. FEMS Microbiol. Rev. 2010, 34, 753-763. [CrossRef] [PubMed]

41. Abbas, H.A. Inhibition of Virulence of Pseudomonas aeruginosa: A Novel Role of Metronidazole Against Aerobic Bacteria. Res. J. Pharm. Technol. 2015, 8, 1640-1644. [CrossRef]

42. Saleh, M.M.; Abbas, H.A.; Askoura, M.M. Repositioning secnidazole as a novel virulence factors attenuating agent in Pseudomonas aeruginosa. Microb. Pathog. 2019, 127, 31-38. [CrossRef]

43. Armbruster, C.E.; Mobley, H.L.T.; Pearson, M.M. Pathogenesis of Proteus mirabilis Infection. EcoSal Plus 2018, 8. [CrossRef] [PubMed]

44. Rozalski, A.; Sidorczyk, Z.; Kotelko, K. Potential virulence factors of Proteus bacilli. Microbiol. Mol. Biol. Rev. 1997, 61, 65-89. [CrossRef] [PubMed]

45. Mobley, H.L.; Island, M.D.; Hausinger, R.P. Molecular biology of microbial ureases. Microbiol. Rev. 1995, 59, 451-480. [CrossRef] [PubMed]

46. Senior, B.W. The production of HlyA toxin by Proteus penneri strains. J. Med. Microbiol. 1993, 39, 282-289. [CrossRef]

47. Pearson, M.M.; Sebaihia, M.; Churcher, C.; Quail, M.A.; Seshasayee, A.S.; Luscombe, N.M.; Abdellah, Z.; Arrosmith, C.; Atkin, B.; Chillingworth, T.; et al. Complete genome sequence of uropathogenic Proteus mirabilis, a master of both adherence and motility. J. Bacteriol. 2008, 190, 4027-4037. [CrossRef] 
48. Rather, P.N. Swarmer cell differentiation in Proteus mirabilis. Environ. Microbiol. 2005, 7, 1065-1073. [CrossRef]

49. Allison, C.; Emody, L.; Coleman, N.; Hughes, C. The role of swarm cell differentiation and multicellular migration in the uropathogenicity of Proteus mirabilis. J. Infect. Dis. 1994, 169, 1155-1158. [CrossRef]

50. De Kievit, T.R.; Parkins, M.D.; Gillis, R.J.; Srikumar, R.; Ceri, H.; Poole, K.; Iglewski, B.H.; Storey, D.G. Multidrug efflux pumps: Expression patterns and contribution to antibiotic resistance in Pseudomonas aeruginosa biofilms. Antimicrob. Agents Chemother. 2001, 45, 1761-1770. [CrossRef]

51. Askoura, M.; Youns, M.; Halim Hegazy, W.A. Investigating the influence of iron on Campylobacter jejuni transcriptome in response to acid stress. Microb. Pathog. 2020, 138, 103777. [CrossRef] [PubMed]

52. Gomez-Suarez, C.; Pasma, J.; van der Borden, A.J.; Wingender, J.; Flemming, H.C.; Busscher, H.J.; van der Mei, H.C. Influence of extracellular polymeric substances on deposition and redeposition of Pseudomonas aeruginosa to surfaces. Microbiology 2002, 148, 1161-1169. [CrossRef]

53. Belas, R.; Suvanasuthi, R. The ability of Proteus mirabilis to sense surfaces and regulate virulence gene expression involves FliL, a flagellar basal body protein. J. Bacteriol. 2005, 187, 6789-6803. [CrossRef] [PubMed]

54. Hegazy, W.A.H.; Abbas, H.A. Evaluation of the role of SsaV 'Salmonella pathogenicity island-2 dependent type III secretion system components on the virulence behavior of Salmonella enterica serovar Typhimurium. Afr. J. Biotechnol. 2017, 16, 718-726. [CrossRef]

55. Schaffer, J.N.; Norsworthy, A.N.; Sun, T.T.; Pearson, M.M. Proteus mirabilis fimbriae- and urease-dependent clusters assemble in an extracellular niche to initiate bladder stone formation. Proc. Natl. Acad. Sci. USA 2016, 113, 4494-4499. [CrossRef]

56. Jiang, W.; Ubhayasekera, W.; Breed, M.C.; Norsworthy, A.N.; Serr, N.; Mobley, H.L.T.; Pearson, M.M.; Knight, S.D. MrpH, a new class of metal-binding adhesin, requires zinc to mediate biofilm formation. PLoS Pathog. 2020, 16, e1008707. [CrossRef] [PubMed]

57. Pawar, S.; Ashraf, M.I.; Mujawar, S.; Mishra, R.; Lahiri, C. In silico Identification of the Indispensable Quorum Sensing Proteins of Multidrug Resistant Proteus mirabilis. Front. Cell Infect. Microbiol. 2018, 8, 269. [CrossRef] [PubMed]

58. Wang, M.C.; Chien, H.F.; Tsai, Y.L.; Liu, M.C.; Liaw, S.J. The RNA chaperone Hfq is involved in stress tolerance and virulence in uropathogenic Proteus mirabilis. PLoS ONE 2014, 9, e85626. [CrossRef] [PubMed] 